Article

\title{
Renewable Energy and Economic Performance in the Context of the European Green Deal
}

\author{
Mihaela Simionescu ${ }^{1,2, *} \mathbb{D}$, Carmen Beatrice Păuna ${ }^{2}$ and Tiberiu Diaconescu ${ }^{2}$ \\ 1 Faculty of Management, University of Social Sciences, 9 Sienkiewicza St., 90-113 Łódź, Poland \\ 2 Institute for Economic Forecasting, Romanian Academy, Calea 13 Septembrie 13, 050713 Bucharest, Romania; \\ pauna_carmen@ipe.ro (C.B.P.); diaconescutiberiu@gmail.com (T.D.) \\ * Correspondence: mihaela.simionescu@ipe.ro
}

Received: 4 November 2020; Accepted: 3 December 2020; Published: 6 December 2020

check for updates

\begin{abstract}
The European Green Deal considers the increase in the share of renewable energy in final energy consumption (REFEC) among the main targets for achieving sustainable EU economies. In this context, the main aim of this paper is to provide an empirical evaluation of the relationship between GDP, global competitiveness index (GCI) and renewable energy consumption. According to panel data models based on the fully modified ordinary least squares method (FMOLS), there is a positive effect of renewable energy consumption progress on GDP and GCI growth, and also a positive influence of economic growth on renewable energy consumption in the period 2007-2019 in the EU countries. The energy consumption is more influenced by economic growth rather than economic competitiveness. Few scenarios were proposed for economic growth and share of renewable sources (RESs) in the final consumption using as forecasting method the proposed panel data models. The cluster analysis suggested two groups of countries according to RES share in gross final energy consumption (GFEC). The first group includes six countries (Sweden, Denmark, Finland, Latvia, Portugal and Austria) that fixed a target of $30 \%$ or more, while the second one refers to countries with lower targets. Some policy recommendations are provided for the EU countries to enhance the utilization of renewable energy.
\end{abstract}

Keywords: renewable energy sources; energy consumption; GDP; GCI; scenarios; panel data models; clustering

\section{Introduction}

Nowadays, the energy transition represents a main goal of the European Green Deal that is considered a roadmap of key climate policies for the next decades. The climate and energy policy at the EU level is structured around three pillars (a) the share of renewable energy in final energy consumption (REFEC), (b) reduction of greenhouse gas (GHG) emissions compared to 1990 and (c) better energy efficiency [1]. For all these pillars, targets of 20\% have been established [2].

At global level, the importance of renewable sources (RESs) in energy consumption has grown lately. The benefits of the RES utilization concern environmental protection and energy security. Renewable energies ensure the decarbonization of the energy system. The replacement of the fossil fuels with RESs brings less emissions of GHG [3]. The EU's policy concerning the issues related to climate change is based on the EU emissions trading system (EU ETS) that is focused on the reduction of GHGs level. However, the EU needs better supportive financing conditions and a more stable legal framework to reduce GHGs emissions.

The EU energy strategy is based on more objectives that contribute to the sustainable development of the member states: A less energy dependent EU due to energy costs, security of energy supply and costs, better energy networks, climate change mitigation and environmental protection. The National 
Renewable Energy Action Plans (NREAPs) describe the policies related to regional planning, promoting environmental protection, non-discriminatory access to electricity and fast adaptation to the RESs. These goals might be achieved by each EU member state that fixed its own targets [4]. These policy objectives might be achieved with investment in renewable energy projects that are supported by the European Central Bank. There are specific EU funds for innovation in technological processes, pilot plants and smart grids. The EU Cohesion Policy (2014-2020) made investments in sustainable energy to support innovation, renewable energy, energy efficiency and smart energy infrastructure [5-7].

We identified, as a gap in literature reviews, the lack of empirical studies to highlight the role of energy based on renewable and non-renewable sources in enhancing economic performance. Most approaches limit to economic growth and energy consumption, but we also used global index of competitiveness as proxy for economic performance. A comparative analysis is made between the role of energy consumption from renewable sources in supporting a competitive economy and the role of energy consumption from renewable sources in accelerating competitiveness. Our statistical analysis is connected with policy initiatives reflected by the European Green Deal. The research question is focuses on the role of renewable energy in enhancing economic growth and the importance of economic development and environmental taxes in supporting the energy consumption based different sources. In this specific context, the central objective of the paper is to analyze the relationship between the share of RESs in energy consumption and GDP in the EU and UK in the period 2007-2019 by employing some panel data models.

The approach starts from the Cobb-Douglas function, where energy consumption is included in the list of explanatory variables. In another type of model, the energy consumption based on renewable and non-renewable sources is explained based on economic growth. Energy has represented a significant input factor for production since before the Industrial Revolution, where the energy has been produced from various renewable sources. The demand for energy has intensively increased in the 21st century, which brings the necessity to exploit RES better with advanced technology and to provide cheaper energy.

The results indicate that energy consumption presents a direct and statistically significant impact on output, while economic development enhances the energy consumption. In terms of policy initiatives, energy consumption based on RESs should be promoted due to environmental benefits, but also due to the economic conditions of the EU countries. There are two categories of RESs, all these sources having infinite existence: Conventional RESs (e.g., biomass and hydro energy) and new RESs (wind, geothermal energy, solar energy, etc.) [6]. The Directive 2009/28/EC establishes specific targets at national level for the shares of RESs in the gross final energy consumption (GFEC) [8] based on the aim of reaching the $20 \%$ of RESs in GFEC by 2020. By 2030, this share should be at minimum level of $27 \%$ as the 2030 Climate and Energy Policy Framework indicated. The period 2014-2024 was designated by the United Nations as the Decade of Sustainable Energy. The International Energy Agency predicted that the share of electricity generation from different renewable sources will be $39 \%$ by 2050 and $\mathrm{CO}_{2}$ emission will reduce by $50 \%$, while temperature will be reduced by about $2{ }^{\circ} \mathrm{C}$.

The share of RESs in GFEC is defined as the degree of renewable energy use and the measure to which different nuclear fuels and/or the fossil were replaced by RESs to achieve the EU decarbonization. The GFEC sums up the energy utilized by final consumers and self-consumption of power plants and grid losses. On the other hand, gross inland energy consumption (GIEC) summarizes the final energy demand of a certain zone or country.

This paper is structured on more sections: The next section introduces the research literature, while the method and the empirical results are described in the next two sections. In Section 5, relevant comments of the obtained results are provided. In the last section, few conclusions, implications and recommendations for further research are presented. 


\section{Literature Review}

An important issue that should be considered is related to RESs volatility that could be managed by elements that retain common plants, but also grid extensions, a pumped storage that makes energy management more efficient, and lignite and nuclear power plants [6].

Beside studies highlighting the practical effects of renewable energy, fewer studies focused on the effects on the economic development in different countries. The energy consumption based on RESs influence the economy and, consequently, the population standard of living. The aim of current research is to estimate the effect of the energy consumption based on renewable and non-renewable sources on the economic growth, but also the effects of economic development on the energy consumption by employing panel data techniques. The gaps in RESs supply are present and these are due to regional gaps at cost level. For example, cheaper hydro is present in those regions with mountains and moving water. Cheap biomass is provided in regions with a lot of forests. Coastal regions in the Northern Europe benefit from cheaper wind and PV presents a comparative advantage in the Southern Europe. Without neglecting regional differences, this paper does not analyze regional gaps because of lack of data availability for economic costs [7].

In December 2019, the UN Conference of the Parties from Madrid described the new climate strategy at European level known as European Green Deal [9]. As this new strategy suggests, by 2050 a zero-emission economy will be established for the EU economy $[10,11]$. This objective is connected with a high growth of RESs in the energy mix in case of the EU countries.

In the last years, the energy policy in the EU is based on few key objectives: Energy security in competitive economics, environmental and climate protection [12,13]. In this context, economic and policy decision makers agreed that the application of the European Green Deal is compulsory. The application of this strategy should ensure high environment quality and faster technological progress [14].

Despite the Covid-19 pandemic and expected economic crisis, Green Deal remains a priority for the EU energy policy. Its implementation required financial support for passing to renewable sources and suitable programs enhancing energy efficiency after coronavirus period. Beside the initiatives of the EU institutions and governments, international cooperation with third party countries should not be omitted in order to support green industry carbon adjustment, and technology transfers [15].

Another important topic in this field is related to energy efficiency. The decoupling between economic growth and energy consumption is made to enhance energy efficiency in developed countries. Various environmental regulations and evolutions on national and global energy market have a significant impact on energy efficiency. This impacts the conditions of the policy initiatives in this field. According to Bigerna et al. (2020), there are different national behaviors related to the impact of market and environmental regulations on energy efficiency in the EU countries. Stringent regulatory policies decreased energy efficiency. In the case of much regulated electricity markets like in Sweden, Poland, France and Ireland, the growth of product market regulation indices contributed to energy efficiency decrease. Countries like Spain, Portugal, UK, Slovakia and Czech Republic with deregulated markets registered progress in energy efficiency due to deregulation [16]. The Just Energy Transition (JET) Fund represents the financial support associated to the Just Transition Mechanism (JTM) in order to support the decarbonization process in the EU. The budget of this fund is attributed to those countries and regions encountering difficulties in achieving economic zero emissions [16,17].

The access to cheap energy will improve the economic development and the societal well-being. The consequences of poverty will be alleviated [2-4]. The dynamic development of the global economy supposes increasing energy demand for all sectors of the economy. Nowadays, the evolution energy sector is designed to, not only, support the economic growth, but also the economic competitiveness of all the countries [5-8].

Almost all studies in the literature explain the connection between the economic growth and the renewable energy consumption in more countries, but the EU member states have not been analyzed yet. 
Final energy consumption in the transport sector, industry and other sectors is based on renewable sources, and also solid fuels, oil products, nuclear heat, gas, waste and electrical energy. It sums up the energy consumption in the mentioned sectors [17]. The energy consumption from RESs refers to renewable portion of waste, tidal power, sun energy (thermal, photovoltaic and concentrate), hydroelectric power, wind energy, geothermal energy and biofuels.

The use of energy from renewable sources is related to the objective of having $40 \%$ less GHG emissions by $2030[18,19]$. In this context, the EU states take different measures to stimulate the RESs deployment.

There are many studies [20-32] focusing on the connection between renewable energy consumption and various indicators at macroeconomic level using different methods. Most of studies analyzed this relationship of obtaining a long-running relationship between economic growth and the energy consumption based on RESs. Few papers proved the capacity of energy consumption to stimulate economic growth. The analysis was made for different regions: Gulf Cooperation Council (GCC) countries [24], 15 ex-communist countries [27], new EU member states [23], 42 developing countries [25], nine South and Southeast Asian countries [28], leading countries having maximum shares of RES at a global level [26], China [33] and Algeria [34]. Another study proposed two types of models for evaluating the relationship between income and consumption of renewable energy in emerging economies [19]. A co-integration relationship was observed in this case, the real per capita growth generating a significant increase in renewable energy consumption per capita. An increase in the real income per capita by $1 \%$ generates a growth of the renewable energy per capita consumption by $3.5 \%$ in the less developed economies. Other papers used renewable energy sustainability index in relation with the degree of economic development in the EU-15 states [20]. The connection between energy per capita and economic growth was studied in 19 Eurozone countries [21]. The impact of renewable, but also of non-renewable energy consumption on output was evaluated for few OIC countries [29], OECD countries [30] and China [31].

The GDP as dependent variable is explained using various factors (renewable energy consumption, and production factors like labor force, fixed and gross capital formation (see Svenfelt et al. [32], Aslan [33], Sasana and Ghozali [34] or Destek and Aslan [35])). These variables will also be considered in our empirical research. Other predictors in the models could be: Urbanization (China [36]), technological innovation (China [37]), residential sector [38], $\mathrm{CO}_{2}$ emissions and the degree of financial development (GCC countries [39]). The advantages of technologies for renewable energy are mostly observed for emerging countries [40].

Few groups of countries were identified based on energy consumption and output in countries with different level of economic development [41]. For example, Austria, Latvia, Denmark, Finland and Sweden have already reached the target related to share of renewable energy in GFEC set for 2020. Other EU countries encountered difficulties in achieving the targets for 2020 (Belgium, France, Luxembourg, Netherlands and UK). Other researches made predictions for energy consumption taking into account the connection of this variable with economic growth, financial development, export, import, and the capitals for Japan [42] and China [43].

Considering the objective of European Green Deal to increase the share of RESs energy in the total energy consumption for a sustainable economy, the goal of our paper is to observe the dynamics of the final energy consumption linked to GDP as a measure of economic growth and to global competitiveness index (GCI) as a measure of competitiveness in the EU countries between 2007 and 2019. Unlike previous studies, we also study the relationship between economic competitiveness and energy consumption. Even if most of the studies focused on the benefits of RES in terms of environmental quality and less GHG emissions, this analysis focuses on the economic impact of renewable energy consumption. We achieved this goal by conducting an empirical research in two directions: (a) the effect of renewable energy consumption on output (GDP) and GCI using panel data models, (b) the impact of economic growth and environmental taxes on the renewable energy consumption using panel data models and (c) simulations related to economic growth and share of the 
energy based renewable elements in the total energy consumption based on the proposed panel data models using fully modified ordinary least squares method (FMOLS) method of estimation.

\section{Methodology and Empirical Model}

We started from a basic function of production. Beside traditional types of inputs, we will also used renewable and non-renewable energy to explain the aggregate production. Let us start from the standard Cobb-Douglas production function:

$$
Y_{t}=A_{t} \cdot K_{t}^{\alpha} \cdot L_{t}^{1-\alpha}
$$

$Y_{t}$ GDP at time $t$,

$L_{t}$-labor force at time $t$,

$K_{t}$-capital at time $\mathrm{t}$,

$\alpha$-parameter $(0<\alpha<1)$,

$A_{t}$-coefficient including total factor productivity composed by efficiency and technological progress.

The analysis was based on the hypothesis that technology is determined by skilled human capital. Beside factors like capital formation and labor force, we added the consumption of energy from renewable, but also non-renewable sources as explanatory variables and the model was expressed in a linear form. The Cobb-Douglas function was chosen in this case in order to show that beside labor and capital formation, the output was influenced by other factors. The novelty of our research was given by the consideration of energy factors like important determinants of output and competitiveness. Moreover, beside output we considered the index of competitiveness as dependent variable to reflect economic performance.

The dependent variable was represented by GDP and GCI, respectively. The panel data approach was based on the EU countries and the UK in the period 2007-2019, where $i$ is the index for country and $t$ is the index for time.

$$
\begin{aligned}
& \ln G D P_{i t}=\ln \left(A_{i t}\right)+\alpha \cdot \ln \left(K_{i t}\right)+\beta \cdot \ln \left(L_{i t}\right)+\gamma \cdot \ln \left(E R_{i t}\right)+\varepsilon_{i t} \\
& \ln G D P_{i t}=\ln \left(A_{i t}\right)+\alpha \cdot \ln \left(K_{i t}\right)+\beta \cdot \ln \left(L_{i t}\right)+\gamma \cdot \ln \left(E N_{i t}\right)+\varepsilon_{i t} \\
& \ln G C I_{i t}=\ln \left(A_{i t}^{\prime}\right)+\alpha^{\prime} \cdot \ln \left(K_{i t}\right)+\beta^{\prime} \cdot \ln \left(L_{i t}\right)+\gamma^{\prime} \cdot \ln \left(E R_{i t}\right)+\varepsilon_{i t}^{\prime} \\
& \ln G C I_{i t}=\ln \left(A_{i t}^{\prime}\right)+\alpha^{\prime} \cdot \ln \left(K_{i t}\right)+\beta^{\prime} \cdot \ln \left(L_{i t}\right)+\gamma^{\prime} \cdot \ln \left(E N_{i t}\right)+\varepsilon_{i t}^{\prime}
\end{aligned}
$$

$\alpha, \beta, \gamma, \alpha^{\prime}, \beta^{\prime}, \gamma^{\prime}$-parameters,

$\varepsilon_{i t}, \varepsilon_{i t}^{\prime}$-error terms.

The cointegration relationship between energy consumption and output was checked using Kao test, after we established that the data series were integrated of the same order. Kao (1999) proposed five cointegration tests, the Augmented Dickey-Fuller statistic (ADF statistic) being based on the following regression model [44]:

$$
\begin{gathered}
\widehat{\varepsilon_{i t}}=\rho \widehat{\varepsilon_{i t-1}}+\sum_{j=1}^{p} v_{j} \Delta \widehat{\varepsilon_{i t-j}}+v_{i t p} \\
A D F=\frac{t_{A D F}+\frac{\sqrt{6 N \sigma_{v}}}{2 \widetilde{\sigma_{0 v}}}}{\sqrt{\frac{\widehat{\sigma}_{0 v}^{2}}{2 \widehat{\sigma}_{\mathrm{v}}^{2}}+\frac{3 \widehat{\sigma}_{0 v}^{2}}{10 \bar{\sigma}_{\mathrm{v}}^{2}}}}
\end{gathered}
$$

$t_{A D F}-\mathrm{t}$ statistic corresponding to $\rho$. 
In the case of long-running relationships between data series, we can make estimations using FMOLS known as fully modified ordinary least squares method introduced by Pedroni (2000) [45]. This FMOLS estimator is based on corrections for endogeneity and serial correlation associated to OLS estimator.

$$
\hat{\beta}_{\mathrm{NT}}^{*}-\beta=\left[\sum_{\mathrm{t}=1}^{\mathrm{N}} \hat{\mathrm{L}}_{22 \mathrm{t}}^{-2} \sum_{\mathrm{t}=1}^{\mathrm{T}}\left(\mathrm{u}_{\mathrm{it}}-\overline{\mathrm{u}}_{\mathrm{i}}\right)^{2}\right] \sum_{\mathrm{t}=1}^{-1} \hat{\mathrm{L}}_{11 \mathrm{t}}^{-1} \hat{\mathrm{L}}_{22 \mathrm{t}}^{-1}\left[\sum_{\mathrm{t}=1}^{\mathrm{T}}\left(\mathrm{u}_{\mathrm{it}}-\overline{\mathrm{u}}_{\mathrm{t}}\right) \mu_{\mathrm{it}}^{*}-\mathrm{T} \hat{\gamma}_{\mathrm{i}}\right]
$$

$\hat{\beta}_{N T}$-standard panel OLS estimator,

$\bar{u}_{i}$-individual specific means.

$$
\begin{gathered}
\mu_{i t}^{*}=\mu_{i t}-\frac{\hat{L}_{21 i}}{\hat{L}_{22 i}} \Delta x_{i t} \\
\hat{\gamma}_{i} \equiv \hat{\Gamma}_{21 i}+\hat{\Omega}_{21 i}^{0}-\frac{\hat{L}_{21 i}}{\hat{L}_{22 i}}\left(\hat{\Gamma}_{22 i}+\hat{\Omega}_{22 i}^{0}\right)
\end{gathered}
$$

$\hat{\Omega}_{i}$-long-term dispersion of residual (scalar),

$\hat{\Omega}_{i}^{0}$-contemporaneous covariance,

$\Gamma_{i}$-weighted sum of autocovariances,

$\hat{L}_{i}$-lower triangular decomposition of $\hat{\Omega}_{i}$.

The conditional long-run variances are:

$$
\begin{aligned}
& \hat{L}_{11 i}=\hat{\sigma}_{u}^{2}-\frac{\hat{\sigma}_{u \varepsilon}^{2}}{\hat{\sigma}_{\varepsilon}^{2}} \\
& \hat{L}_{22 i}=\hat{\sigma}_{\varepsilon}^{2}
\end{aligned}
$$

$T \sqrt{N}\left(\hat{\beta}_{N T}^{*}-\beta\right) \rightarrow N(0, v)$, where $T \rightarrow \infty$ and $N \rightarrow \infty$ $v=2$, if $\bar{u}_{i}=\bar{y}_{i}=0$ and else $\mathrm{v}=6$

\section{Model Estimations and Results}

Our models were based on more variables in the logarithm form: GDP, energy consumption from RESs, energy consumption from nonRESs, gross capital formation as percent of GDP denoted as capital, number of employed people in thousand persons from 15 to 64 years denoted as labor, GCI and share of environmental taxes with respect to total volume of tax revenues. The data was provided for all the EU countries and UK for the period 2007-2019. The data in this level are not stationary,

\begin{tabular}{|c|c|c|c|c|}
\hline Variable & Notation & Type of Method & $\begin{array}{c}\text { Dependent } \\
\text { Variable }\end{array}$ & $\begin{array}{c}\text { Explanatory } \\
\text { Variables }\end{array}$ \\
\hline logarithm of GDP & ln_GDP & Panel data models & ln_GDP & $\begin{array}{c}\ln \_K \\
\ln \_L \\
\ln \_E R\end{array}$ \\
\hline $\begin{array}{l}\text { logarithm of energy } \\
\text { consumption from } \\
\text { renewable sources } \\
\text { and energy }\end{array}$ & ln_ER & Panel data models & ln_GDP & $\begin{array}{l}\ln \_K \\
\ln \_L \\
\ln \_ \text {EN }\end{array}$ \\
\hline $\begin{array}{l}\text { logarithm of energy } \\
\text { consumption from } \\
\text { non-renewable sources }\end{array}$ & ln_EN & Panel data models & ln_GCI & $\begin{array}{l}\ln \_K \\
\ln \_L \\
\ln \_E R\end{array}$ \\
\hline
\end{tabular}
but the logarithmized forms provided stationary data sets. The dependent variables are represented by logarithm of GDP, energy consumption from RESs and from other sources. The variables and methods used in this research are described in Table 1.

Table 1. Variables and methods used in this analysis. 
Table 1. Cont.

\begin{tabular}{|c|c|c|c|c|}
\hline Variable & Notation & Type of Method & $\begin{array}{l}\text { Dependent } \\
\text { Variable }\end{array}$ & $\begin{array}{l}\text { Explanatory } \\
\text { Variables }\end{array}$ \\
\hline logarithm of GCI & ln_GCI & Panel data models & ln_GCI & $\begin{array}{c}\ln \_K \\
\ln \_L \\
\ln \_ \text {EN }\end{array}$ \\
\hline $\begin{array}{l}\text { logarithm of share of } \\
\text { environmental taxes in } \\
\text { total tax revenues }\end{array}$ & ln_ET & Panel data models & ln_ER & $\begin{array}{l}\ln \_ \text {GDP } \\
\text { ln_ET }\end{array}$ \\
\hline $\begin{array}{l}\text { logarithm of gross } \\
\text { capital formation }\end{array}$ & ln_K & Panel data models & ln_EN & $\begin{array}{l}\text { ln_GDP } \\
\text { ln_ET }\end{array}$ \\
\hline $\begin{array}{l}\text { logarithm of number of } \\
\text { employed people } \\
\text { (labor force) }\end{array}$ & ln_L & $\begin{array}{l}\text { Cluster analysis } \\
\text { (K-means method) }\end{array}$ & \multicolumn{2}{|c|}{$\begin{array}{c}\text { Groups of countries according to } \\
\text { share of RESs in energy } \\
\text { consumption }\end{array}$} \\
\hline
\end{tabular}

Energy consumption is computed by authors based on intermediate data provided by Eurostat and Statista, being expressed in Gigawatt-hour. GDP in comparable prices (dollars 2010), gross capital formation as percent of GDP, number of employed people, share of environmental taxes in final volume of revenues from taxes and social contributions are provided by Eurostat. On the other hand, GCI is taken from reports of World Economic Forum. Environmental tax revenues are based on four types of taxes related to energy, transport, resource and pollution. GCI combines the macroeconomic and the microeconomic approaches of competitiveness into a unique index. Descriptive statistics are presented in Table 2.

Table 2. Descriptive statistics.

\begin{tabular}{cccccccc}
\hline & ln_GDP & ln_GCI & ln_K & ln_L & ln_EN & ln_ER & ln_ET \\
\hline Mean & 12.06906 & 1.556995 & 3.074276 & 8.208306 & 10.49143 & 8.597901 & 1.982199 \\
Median & 12.12941 & 1.526056 & 3.077312 & 8.348064 & 10.51414 & 8.674551 & 1.998774 \\
Maximum & 14.98566 & 1.806648 & 3.723281 & 10.64766 & 13.17182 & 11.32660 & 2.463853 \\
Minimum & 8.853994 & 1.350667 & 2.322388 & 5.068904 & 7.440493 & 1.226712 & 1.463255 \\
Std. Dev. & 1.567587 & 0.107930 & 0.201214 & 1.411044 & 1.443351 & 1.792421 & 0.231666 \\
Skewness & 0.084980 & 0.186539 & -0.257684 & -0.241339 & -0.038446 & -1.167402 & -0.230086 \\
Kurtosis & 2.190994 & 1.763169 & 4.536494 & 2.547196 & 2.279723 & 5.505523 & 2.304829 \\
Jarque-Bera & 9.538805 & 23.29559 & 36.66043 & 6.113889 & 7.324102 & 163.7166 & 9.701326 \\
Probability & 0.008485 & 0.000009 & 0.000000 & 0.047031 & 0.025680 & 0.000000 & 0.007823 \\
Sum & 4043.136 & 521.5934 & 1029.882 & 2749.783 & 3514.628 & 2880.297 & 664.0368 \\
Sum Sq. Dev. & 820.7483 & 3.890763 & 13.52270 & 665.0087 & 695.8094 & 1073.066 & 17.92546 \\
\hline
\end{tabular}

Own results.

In general, the EU countries, including the UK, had a tendency of growth for GDP in the period 2007-2019. However, an output reduction was observed in Greece since 2008 because of the global economic crisis. The highest decrease was registered in Greece in 2011, when GDP fell by $0.09 \%$ in 2011 compared to 2010. The decline in GDP in Greece is explained by austerity measures in order to improve primary fiscal balance with an increase by 15\% of output in the period 2009-2019 despite the financial crisis. The GDP in Greece registered growth only since 2017. Luxembourg presents outlier values for GDP, the maximum output being registered in 2019 , when it grew by $2.3 \%$ compared to 2018. The intensive export and diversified industrialization made Luxembourg the most competitive country in the world.

Our empirical analysis follows two directions:

- Investigation of the cointegration relationship between these variables;

- Construction of panel fully modified least squares models to explain GDP and energy consumption from RESs and from non-RESs sources. 
According to Kao Residual Cointegration Test for all the data in logarithm, we have a cointegration relationship between for GDP, GCI, human capital (labor force), capital formation, environmental taxes, energy consumption from renewable resources and respectively non-renewable sources. The computed $\mathrm{t}$-statistic of Kao test is -7.84 and the corresponding $p$-value is 0 , which implies the rejection of null assumption of no cointegration at $5 \%$ level of significance.

Starting from Cobb-Douglas function, we explained the GDP growth based on production factors (labor and capital) and energy consumption from renewable, respectively non-renewable sources. In another approach, we explained the energy consumption from various types of sources based on GDP growth and changes in share of environmental taxes in total revenues. The estimation method in the case of panel data models is FMOLS.

According to panel data model in Table 3, there is a positive correlation between GDP growth and the changes in labor force, capital formation and energy consumption from renewable sources. The results are consistent with the economic theory, highlighting that energy consumption from renewable sources is a driver of economic growth. An increase in gross capital formation by one percent determined, in average, an increase in GDP by 1.35 percentage points. This implies that capital formation has the highest contribution to output growth. Each increase in the number of employed people by one percentage point generated, in average, a GDP growth by 0.14 percentage points. The output grew by $0.78 \%$ in average in the period $2007-2019$ at each increase in energy consumption from RESs by one percentage point.

Table 3. Panel data model based on fully modified ordinary least squares method (FMOLS) estimators to explain output growth in the EU countries and UK (2007-2019).

\begin{tabular}{ccccc}
\hline Explanatory Variable & Estimate & Standard Error & Value of Statistic & $p$-Value \\
\hline $\ln \_$L & 0.149895 & 0.033589 & 4.462591 & 0.0000 \\
$\ln$ KK & 1.350711 & 0.117257 & 11.51926 & 0.0000 \\
$\ln$ ER & 0.782169 & 0.027571 & 28.36944 & 0.0000 \\
Coeff. of determination & 0.607611 & Mean for dep. variable & 12.11521 \\
Adjusted coef. of determination & 0.605038 & Standard dev. for dep. variable & 1.594043 \\
Std. Error for regression & 1.001792 & Sum of squared residuals & 306.0944 \\
Long-term variance & 1.128353 & & \\
\hline
\end{tabular}

Own results.

According to panel data model in Table 4, positive connection was observed between GDP growth and the changes in labor force, capital formation and energy consumption from non-renewable sources. The last variable has the highest contribution to economic growth. The output grew by $1.06 \%$ in average in the period 2007-2019 at each increase in energy consumption from non-renewable sources by one percentage point. In this case, the contribution of capital and labor force is underestimated compared to previous panel data model. The growth of the number of employed people by one percentage point generated, in average, an increase in GDP by only 0.02 percentage points. in the growth of gross capital formation by one percent implied, in average, an increase in GDP by 0.22 percentage points.

Table 4. Panel data model based on FMOLS estimators to explain output growth in the EU countries and UK (2007-2019).

\begin{tabular}{ccccc}
\hline Explanatory Variable & Estimate & Standard Error & Value of Statistic & $p$-Value \\
\hline $\ln \_L$ & 0.028586 & 0.012915 & 2.213477 & 0.0276 \\
$\ln \_K$ & 0.227072 & 0.049753 & 4.563947 & 0.0000 \\
$\ln$ EN & 1.062056 & 0.011820 & 89.84871 & 0.0000 \\
Coeff. of determination & 0.937389 & Mean for dep. variable & 12.11521 \\
Adjusted coef. of determination & 0.936978 & Standard dev. for dep. variable & 1.594043 \\
Std. Error for regression & 0.400170 & Sum of squared residuals & 48.84147 \\
Long-term variance & 0.162120 & & \\
\hline
\end{tabular}


According to panel data model in Table 5, there is a direct connection between GCI growth and the changes in labor force, capital formation and energy consumption from renewable sources. The results are consistent with the economic theory, highlighting that energy consumption from renewable sources could be a driver of economic competitiveness. The GCI grew by $0.014 \%$ in average in the period 2007-2019 at each increase in energy consumption from RESs by one percentage point. The impact of labor force, capital and energy consumption based on renewable sources on GCI is lower than the impact of the same factors on GDP.

Table 5. Panel data model based on FMOLS estimators to explain global competitiveness index (GCI) growth in the EU countries and UK (2007-2019).

\begin{tabular}{ccccc}
\hline Explanatory Variable & Estimate & Standard Error & Value of Statistic & $p$-Value \\
\hline $\ln \_$L & 0.029648 & 0.007585 & 3.908883 & 0.0001 \\
$\ln \_K$ & 0.389238 & 0.025788 & 15.09382 & 0.0000 \\
$\ln \_$ER & 0.014947 & 0.005880 & 2.542232 & 0.0115 \\
Coeff. of determination & -0.524890 & Mean for dep. Variable & 1.557964 \\
Adjusted coef. of determination & -0.534923 & Standard dev. for dep. Variable & 0.107850 \\
Std. Error for regression & 0.133618 & Sum of squared residuals & 5.427554 \\
Long-term variance & 0.039286 & & \\
\hline
\end{tabular}

Own results.

According to panel data model in Table 6, there is a positive correlation between GCI growth and the changes in energy consumption from non-renewable sources. The GCI grew by $0.02 \%$ in average in the period 2007-2019 at each increase in energy consumption from non-RESs by one percentage point. The impact of labor force, capital and energy consumption based on non-renewable sources on GCI is lower than the impact of the same factors on GDP.

Table 6. Panel data model based on FMOLS estimators to explain GCI growth in the EU countries and UK (2007-2019).

\begin{tabular}{ccccc}
\hline Explanatory Variable & Estimate & Standard Error & Value of Statistic & $p$-Value \\
\hline $\ln$ _L & 0.025830 & 0.007432 & 3.475677 & 0.0006 \\
$\operatorname{ln\_ K}$ & 0.345429 & 0.029141 & 11.85366 & 0.0000 \\
ln_ER & 0.027956 & 0.006864 & 4.072923 & 0.0001 \\
Coeff. of determination & 0.486382 & Mean for dep. Variable & 1.557964 \\
Adjusted coef. of determination & 0.496161 & Standard dev. for dep. Variable & 0.107850 \\
Std. Error for regression & 0.131920 & Sum of squared residuals & 5.290492 \\
Long-term variance & 0.037243 & & \\
\hline
\end{tabular}

Own results.

The growth of energy consumption from non-renewable sources was positively related to increase in GDP and share of environmental taxes in total revenues (see Table 7). The model's parameters are significant at $10 \%$ level of significance. An increase in GDP by one percentage point determined, in average, an increase in energy consumption from non-renewable sources by 0.91 percentage points in the period 2007-2019. On the other hand, an increase in share of environmental taxes in total revenues by one percentage point generated a growth of energy consumption from non-RESs by 0.16 percentage points.

The expectations given by economic theory are confirmed and the energy consumption from renewable sources was negatively correlated to share of environmental taxes in total revenues, an increase in the later by one percentage point indicating a decrease in energy consumption from these sources by 0.82 percentage points. Each growth of GDP by one percentage point determined, on average, an increase in energy consumption from RESs by 0.85 percentage points in the period 2007-2019 (see Table 8). 
Table 7. Panel data model based on FMOLS estimators to explain changes in energy consumption from non-renewable sources (RESs) in the EU countries and UK (2007-2019).

\begin{tabular}{ccccc}
\hline Explanatory Variable & Estimate & Standard Error & Value of Statistic & $p$-Value \\
\hline ln_GDP & 0.917428 & 0.014214 & 64.54523 & 0.0000 \\
ln_environmental taxes & 0.167739 & 0.097050 & 1.728381 & 0.0850 \\
Coeff. of determination & 0.943176 & Mean for dep. Variable & 10.52574 \\
Adjusted coef. of determination & 0.937249 & Standard dev. for dep. Variable & 1.465211 \\
Std. Error for regression & 0.367039 & Sum of squared residuals & 37.45151 \\
Long-term variance & 0.113156 & & \\
\hline \multicolumn{2}{c}{ Own results. }
\end{tabular}

Table 8. Panel data model based on FMOLS estimators to explain changes in energy consumption from RESs in the EU countries and UK (2007-2019).

\begin{tabular}{ccccc}
\hline Explanatory Variable & Estimate & Standard Error & Value of Statistic & $p$-Value \\
\hline ln_GDP & 0.849983 & 0.021311 & 39.88457 & 0.0000 \\
ln_environmental taxes & -0.826354 & 0.132386 & -6.242018 & 0.0000 \\
Coeff. of determination & 0.628467 & Mean for dep. Variable & 8.609721 \\
Adjusted coef. of determination & 0.627253 & Standard dev. for dep. Variable & 1.817364 \\
Std. Error for regression & 1.109556 & Sum of squared residuals & 376.7211 \\
Long-term variance & 1.320084 & & \\
\hline \multicolumn{2}{c}{ Own results. }
\end{tabular}

Beside environmental taxes, there are other factors that influence the energy consumption from RESs/non-RESs: Market environment (resource availability and diversity, costs etc.), progress in transport sector, policy regulations and including financial support to achieve cost-competitive renewable energy. Another covariate represented by degree of urbanization was also introduced in the model, but this variable did not have a statistically significant consequence on the energy consumption from RESs/non-RESs.

The countries were located in two clusters according to targets established for RES share in gross final energy consumption in 2020, as Table 9 shows. The K-means method was used to construct the groups of countries. The first cluster includes six countries (Sweden, Denmark, Finland, Latvia, Portugal and Austria) that fixed a target of $30 \%$ or more, while the rest of the countries were placed in the second cluster.

Table 9. Groups of countries considering the targets for the share of RESs in the consumption of energy (K-means method).

\begin{tabular}{ccc}
\hline Country & Cluster & Distance \\
\hline Austria & 1 & 2.833 \\
Belgium & 2 & 4.095 \\
Bulgaria & 2 & 1.095 \\
Croatia & 2 & 3.005 \\
Cyprus & 2 & 4.095 \\
Czech Republic & 2 & 4.095 \\
Denmark & 1 & 7.033 \\
Estonia & 2 & 7.905 \\
Finland & 1 & 0.967 \\
France & 2 & 5.905 \\
Germany & 2 & 0.905 \\
Greece & 2 & 0.905 \\
Hungary & 2 & 4.095 \\
Ireland & 2 & 1.095 \\
Italy & 2 & 0.095 \\
Latvia & 1 & 2.967 \\
Lithuania & 2 & 5.905 \\
\hline
\end{tabular}


Table 9. Cont.

\begin{tabular}{ccc}
\hline Country & Cluster & Distance \\
\hline Luxembourg & 2 & 6.095 \\
Malta & 2 & 7.095 \\
Netherlands & 2 & 3.095 \\
Poland & 2 & 2.095 \\
Portugal & 1 & 6.033 \\
Romania & 2 & 6.905 \\
Slovakia & 2 & 3.095 \\
Slovenia & 2 & 7.905 \\
Spain & 2 & 2.905 \\
Sweden & 1 & 11.967 \\
United Kingdom & 2 & 2.095 \\
\hline Source: Own computations in SPSS.
\end{tabular}

The maximum target was fixed by Sweden (the share of renewable energy in the total level of consumption is $49 \%$ ). That target was already overtaken, since Sweden registered $50 \%$ of the energy consumption from RES in 2020. The Sweden's performance is explained by the combination between high energy consumption and low $\mathrm{CO}_{2}$ emissions based on consistent supply of biomass and moving water. Sweden intensely uses water for electricity generation and produces heating based on bioenergy. Renewable electricity developed faster in this country due to different measures of promotion: Quota system, subsidy scheme and tax regulation procedures. Tax exemptions were applied to promote biofuels utilization in transport and renewable heating in Sweden. Since electricity generation systems are connected to grids, heating plant connection is required for companies in this domain. Suitable policies were implemented by Sweden for RES installations that are implied in wind energy production.

Latvia fixed a target of $40 \%$, considering its huge potential for the utilization of hydropower and biomass. Other renewable sources like solar energy and wind power require more extension in the near future. Tenders, feed-in tariff, and also quota system were commonly used in Latvia to enhance electricity based on RES. In January 2020, the feed-in tariff was eliminated because of serious issues of corruption. The creation and utilization of RES installations are supported by policies. Tax benefits are offered for cooling and heating using RES. In this country, diesel and oil are mixed with biofuels.

With a target of $38 \%$ for the share of RES in total volume of energy consumption, Finland mainly uses wood for energy production due to many forests in this country. On the other hand, wind energy has a very low share in total energy consumption. In case of power plants using biogas and wood fuels, heat bonus is offered. The tender based premium scheme promotes cost effective expansion of RES. The transport sector is based on quota system. Investment in RES is supported by state subsides. Like in Sweden, the implementation of RES installations is encouraged by suitable policies.

Austria is another country with high target in terms of share associated to RES in energy consumption $(34.2 \%)$, bioenergy being the priory renewable energy source in this country. Moreover, Austria is the EU country with the highest hydropower utilization, many companies in this field being focused on innovation that supports a prosperous business environment.

For Portugal, the target is $31 \%$, the main RESs being represented by wind, sun, water and biofuels [46]. Weather conditions in this country influence the utilization of hydropower. In the case of RESs based on plants, a feed-in tariff is utilized for electricity production. For biofuels, quota system is applied while small producers of biofuels benefit from tax exemption. The accession of electricity from RES to grid shall is considered a priority, excepting hydro plants for which the capacity surpasses 30 MW.

Denmark, with a target of $30 \%$ for share of RES in total energy consumption, made huge progress in the RES consumption mainly due to wind power. Net-metering, premium tariff and loan guarantees for creation of wind and solar energy plants were promoted by Denmark. Renewable energy is considered a priority when a grid is used for electricity production. For RES installations utilization in 
Denmark, few policies promoted research, development and demonstration programs and certification schemes associated to wind energy plants. Moreover, there are only two training programs for those who install RES.

Malta fixed the lowest weight of RES in total energy consumption (10\%), being followed by Luxembourg (11\%). The penetration of market for RES in Malta is low, despite measures to support RES energy consumption like feed-in tariff for PV installations, tendering scheme for installations with capacity higher than $1000 \mathrm{kWp}$, subsidy scheme for aerothermal heat pumps and solar water heating systems, wholesalers of fossil fuels and substitution obligation on importers in transport sector, training and certification program for installers.

Significant progress in achieving a higher target was not observed in the case of Luxembourg because of limited budget and eligibility. Feed-in tariff and premium tariff, tender for new photovoltaic energy plants, subsidy schemes for heat based on RESs, quota system in the transport sector are commonly used in Luxembourg. Even if it is not a priority, electricity based on RESs benefits from cost reductions. Support schemes, training program and research, development and demonstration programs for RES installers are promoted in Luxembourg.

The proposed panel data models are used to construct scenarios for GDP growth and final energy consumption from RESs and non-RESs. We are interested in making comparisons between our forecasts for GDP growth and the predictions proposed by OECD and our scenarios for RES share in GFEC and the targets and predictions for this variable provided by PRIMES model for 2020 and 2021.

According to PRIMES models, the forecasts for RES share in GFEC should be in 35.5\% 2020 and $37 \%$ in 2021 [47].

The forecasts for real GDP growths in 2020 and 2021 are computed as an average of the scenarios based on models in Tables 1 and 2. In this case, in each model we consider the values in 2019 for labor force and capital formation. The values for energy consumption from renewable/non-renewable sources are the forecasts based on PRIMES model for 2020 and 2021. The forecasts for RES share in GFEC are based on the model in Table 6. In this model, we employed the GDP forecasts of European Commission for 2020 and 2021 and we kept the share of environmental taxes with respect to volume of revenues in 2019 (see Table 10).

Table 10. Forecasts for real GDP growth and RES share in gross final energy consumption (GFEC) (\%) in the EU countries and UK for 2020.

\begin{tabular}{ccccc}
\hline \multirow{2}{*}{ Country } & \multicolumn{2}{c}{ Real GDP Growth (\%) } & \multicolumn{2}{c}{ RES Share in GFEC (\%) } \\
\cline { 2 - 5 } & Own Scenarios & OECD Forecasts & Own Scenarios & Targets \\
\hline Austria & 8.68 & -4.98 & 31.68 & 34.2 \\
Belgium & 7.02 & -8.92 & 10.52 & 13 \\
Bulgaria & 2.58 & -7.11 & 9.42 & 16 \\
Croatia & 1.53 & -4.08 & 18.70 & 20.1 \\
Cyprus & 2.52 & -7.16 & 10.19 & 13 \\
Czech Republic & 5.97 & -9.58 & 9.53 & 13 \\
Denmark & 3.40 & -5.78 & 23.79 & 30 \\
Estonia & 3.84 & -8.37 & 19.63 & 25 \\
Finland & 4.01 & -7.87 & 40.57 & 38 \\
France & 6.12 & -11.37 & 19.40 & 23 \\
Germany & 5.70 & -6.6 & 12.69 & 18 \\
Greece & 1.19 & -7.99 & 10.14 & 18 \\
Hungary & 2.09 & -7.98 & 9.59 & 13 \\
Ireland & 2.19 & -6.79 & 13.83 & 16 \\
Italy & 1.33 & -11.27 & 11.47 & 17 \\
Latvia & 2.04 & -8.06 & 30.63 & 40 \\
Lithuania & 2.90 & -8.07 & 19.46 & 23 \\
Luxembourg & 6.47 & -6.49 & 12.68 & 11 \\
Malta & 2.34 & -6.78 & 10.19 & 10 \\
Netherlands & 6.09 & -8.01 & 9.68 & 14 \\
Poland & 2.90 & -7.44 & 13.90 & 15 \\
\hline
\end{tabular}


Table 10. Cont.

\begin{tabular}{ccccc}
\hline \multirow{2}{*}{ Country } & \multicolumn{2}{c}{ Real GDP Growth (\%) } & \multicolumn{2}{c}{ RES Share in GFEC (\%) } \\
\cline { 2 - 5 } & Own Scenarios & OECD Forecasts & Own Scenarios & Targets \\
\hline Portugal & 4.65 & -9.35 & 29.47 & 31 \\
Romania & 3.07 & -6.47 & 19.71 & 24 \\
Slovakia & 2.21 & -9.28 & 9.56 & 14 \\
Slovenia & 1.75 & -7.81 & 18.74 & 25 \\
Spain & 2.69 & -11.13 & 20.28 & 20 \\
Sweden & 3.10 & -6.68 & 39.76 & 49 \\
United Kingdom & 3.01 & -11.49 & 13.94 & 15 \\
\hline
\end{tabular}

Source: Own calculations and data provided by OECD and European Environment Agency https://www.eea.europa. eu/data-and-maps/indicators/renewable-gross-final-energy-consumption-4/assessment-4, https://data.oecd.org/ gdp/real-gdp-forecast.htm.

The OECD revised forecasts take into account the effects of COVID-19 on the European economies, while our predictions do not include the potential shocks of the economies, being based on the hypotheses that shocks absorb during one year. We predicted economic growth based on our models, while OECD forecasted economic recession. Our scenarios for RES share in gross final energy consumption present lower values compared to established targets. Only Finland and Sweden will obtain values that are higher than the forecasts in 2020 based on PRIMES model.

We compared own forecasts with OECD forecasts for economic growth in 2021 and we also provide predictions for RES share in GFEC in 2021. The forecasts are made under the hypotheses of economic recovery after COVID-19 (see Table 11).

Table 11. Forecasts for real GDP growth and RES share in GFEC (\%) in the EU countries and UK for 2021.

\begin{tabular}{cccc}
\hline Country & $\begin{array}{c}\text { Real GDP Growth (\%) } \\
\text { Own Scenarios }\end{array}$ & $\begin{array}{c}\text { RES share in GFEC (\%) } \\
\text { Own Scenarios }\end{array}$ \\
\hline Austria & 2.98 & 4.12 & 32.22 \\
Belgium & 7.80 & 6.43 & 11.59 \\
Bulgaria & 3.77 & 2.42 & 10.35 \\
Croatia & 1.55 & 2.68 & 19.86 \\
Cyprus & 1.43 & 1.67 & 10.22 \\
Czech Republic & 6.61 & 7.13 & 10.67 \\
Denmark & 2.81 & 3.65 & 24.29 \\
Estonia & 3.70 & 4.26 & 20.44 \\
Finland & 4.83 & 3.66 & 41.91 \\
France & 3.59 & 7.7 & 20.55 \\
Germany & 3.54 & 5.76 & 13.74 \\
Greece & 1.46 & 4.46 & 11.22 \\
Hungary & 5.60 & 4.58 & 9.65 \\
Ireland & 5.86 & 4.82 & 14.90 \\
Italy & 4.35 & 7.72 & 13.54 \\
Latvia & 7.82 & 6.34 & 32.33 \\
Lithuania & 6.69 & 6.36 & 20.15 \\
Luxembourg & 5.60 & 3.89 & 13.29 \\
Malta & 3.28 & 5.22 & 11.22 \\
Netherlands & 6.55 & 6.56 & 9.48 \\
Poland & 4.92 & 4.76 & 14.18 \\
Portugal & 5.38 & 6.26 & 30.49 \\
Romania & 3.94 & 4.71 & 20.88 \\
Slovakia & 6.72 & 6.42 & 10.66 \\
Slovenia & 5.69 & 4.53 & 19.89 \\
Spain & 7.33 & 7.48 & 21.46 \\
Sweden & 3.70 & 1.65 & 40.15 \\
United Kingdom & 9.01 & 8.99 & 14.22 \\
\hline
\end{tabular}

Source: Own calculations. 
The scenarios for RES share in GFEC in 2021 are higher than those for 2020. Therefore, we anticipated a progress in achieving values that are close to targets. Only Finland and Sweden will obtain values that are higher than the forecasts in 2021 based on PRIMES model.

For Belgium, Bulgaria, Finland, Ireland, Poland, Hungary, Lithuania Latvia, Slovenia, Luxembourg, Slovakia, Sweden and UK, we anticipated a higher economic growth than OECD based on our FMOLS models.

\section{Discussion of Results}

RESs play a central role in achieving the economic development and the environmental protection established on the European sustainable agenda. Most of the studies empirically evaluate the benefits in relation to environment protection. However, a small number of studies have focused analyzed of energy consumption based on RESs on economic development reflected as economic growth (real GDP) and economic competitiveness (GCI). The validity of these empirical results is based on historical data that were processed using advanced statistical methods. The economic benefits of this type of energy could improve the standard of living [48-53].

Lower final energy consumption should be an overall strategy for the EU that might be achieved by better energy efficiency and a higher share of RES. The reduction of final energy consumption ensures less global warming, less dependence of energy imports and more environment protection.

Since 2007, the renewable energy consumption has risen in all EU countries. However, many states need to grow the share of RES to achieve the national targets required by the EU strategy. The suitable national renewable energy policies might be combined with the European initiatives to reduce the gaps [42]. Since a total transition to RESs is not possible, the co-utilization of fossil fuels and various types of renewable energy is the best solution [54].

Fossil fuels represent the principal energy source, but its supply is limited. Moreover, its extraction and conversion generate water pollution and the use of a large surface of land enhancing global warming [55]. Given these issues, renewable energies represent a better alternative to fossil fuels due to reduction of environmental pollution and limitless. Beside these practical advantages, the use of RESs also has an economic advantage by contributing to job creation on the labor market. In this framework, the progress on labor market could enhance economic growth.

In this context, a modified version of Cobb-Douglas was considered to assess the impact of energy consumption from RESs and non-RESs of GDP. On the other hand, the energy consumption from these sources was explained based on GDP and environmental taxes. The FMOLS estimations suggested that energy consumption from non-renewable sources has a stronger impact on output growth compared to renewable sources. This result indicates that efforts for extension of RESs utilization still need to be done to enhance more the use of this source of energy. Our empirical results are consistent with other studies that proved the significant and direct consequence of renewable energy consumption or its share to economic development in OECD countries (inglesi, apergis) in various periods (1985-2005, 1984-2007) and in 38 countries (huge renewable energy consuming states at global level) in 1991-2012 [56]. On the other hand, our findings suggest that agencies of cooperation at international level, national governments, energy policy makers and other associated bodies should cooperate to increase investment in this type of energy for increase of low carbon in the EU countries.

As expected, the economic development of a country enhances the energy consumption. However, the more developed the country is, the higher the use of energy from non-RESs is compared to RESs. This result suggests that developed country should focus more on RESs since non-renewable sources are still more intensively used.

Environmental taxes growth represents a serious brake for energy consumption from RESs, this constraint is enhancing the use of non-renewable sources. In this context, the EU countries should not increase environmental taxes in order to reach the established targets for share of RESs in energy consumption. 
Our forecasts for the EU countries anticipated economic growth in 2020, while OECD forecasts suggest economic decline because of COVID-19 shocks. A progress in RES share in gross final energy consumption in 2021 with respect to 2020 is predicted, but most of the countries are still far from the established targets. Alola confirms that the EU member states did not reach the required targets for share of renewable energy in GFEC [57]. As policy implications, we recommend the intensification of joint projects, statistical transfers and joint support schemes. The risk of electricity failures will reduce due to these connections between countries. The management of volatile wind, solar or other types of RESs should be improved. A resilient energy infrastructure could be ensured by binding this electricity background to achieve two major objectives for energy policy: Incorporation of renewable energy and achievement of energy supply security. Improvement of decarbonization strategy and reduction of energy price volatility might be achieved by reducing the imports made for fossil fuels having non-EU countries as trade partners.

\section{Conclusions and Implications}

All in all, the increase in the renewable energy consumption is a priority for the EU countries since 2010, when massive investments in this type of energy have been made in line with the EU directive. An upward trend was observed for all the countries, but some of them encountered difficulties in achieving the 2020 targets. Spain and Belgium focused more on basic carbon fuels. Countries like Poland reported progress in what concerns the use of energy from RESs, but higher production from these sources is necessary to reach the target for 2020. Sweden, Finland, Austria, and Denmark benefit from favorable climatic conditions that correlated with the lack of fossil fuel resources and determined the minimization of energy consumption.

Sweden has already overtaken the target set for 2020, since it has registered $50 \%$ of the energy consumption from RESs due to its great potential for biomass and moving water and due to many promotion policies for renewable energy. Hydropower and biomass are also intensively used by Latvia that obtained a high share of renewable energy in total consumption. Wood is well used by Finland to produce renewable energy, its performance also being high and supported by state subsidies. Austria set a high target related to share of RES in total energy consumption due to hydropower utilization. With a target higher than $30 \%$, Portugal uses a mix of renewable sources based on wind, sun, water and biofuels.

The United Kingdom developed more the technologies for solar power, but it is still difficult to achieve a high share. The uncertainties brought by Brexit and COVID-19 moved the interest focused on renewable energy among Brits. In this case, the proper decision-making focused more on coal. Germany made great progress in the consumption of nuclear fuels and fossil. Integrated Energy and Climate Programme (Integrierte Energie-und Klimaprogramm) is the principal key in German climate policy [58]. Serious issues in achieving the targets are experiences by Italy, France and Netherlands, the latter preferring natural gas because of the low price instead of renewable energy for which government subsidies are not attractive. Portugal, Romania, Czech Republic and Hungary achieved high shares of RESs in final energy consumption.

Most of the other researches explained the causal relation between economic growth and renewable energy consumption. In addition, we assessed the relationship between GDP and energy consumption from RESs in terms of impact, but also the connection between GCI as a measure of competitiveness and energy consumption from renewable sources. The consumption of renewable energy has a stronger effect on GDP compared to GCI, while the economic development of the European states regarding economic growth and competitiveness enhance the use of renewable energy. If developed countries will use more RESs, the energy security will improve, enhancing the sustainable development. However, the causality from renewable energy consumption and the degree of economic growth was not analyzed in this study. In a future research, the causal relationship should be considered, and non-linear models should be estimated. 
There are other latent factors like energy policies that explain renewable energy, but these could not be included in the econometric models. For example, all the EU countries promoted the acquisition of RES installations. Some countries applied quota system (Sweden, Latvia, Finland, Romania and Portugal) and other used a feed-in tariff (Croatia, Portugal and Latvia). Incentives were utilized in Sweden and generated an intensive use of renewable energy. Other factors from social and fiscal environment, for example urbanization, were not suitable in explaining renewable energy.

Moreover, it is recommended to assess the effect of other factors on renewable energy development: Innovation, technological development, energy production at national level, foreign energy dependence, more investment in $R \& D$, community directives and subsidy policies, know-how at industrial level, entrepreneurial initiatives and environment protection [59-62].

In the post-COVID-19 period, the Green Deal should act like a pillar for the economic growth in the $\mathrm{EU}$ and our findings are in line with the policy agreement for the future mentioned by Elkerbout et al. (2020) [63]. Actually, the economic systems based on capital accumulation presents many weaknesses that could be alleviated by the introduction of other factors in explaining the economic performances like aspects related to energy consumption. Our conclusion is in line with the proposal of Spash (2020) that suggests the alleviation of COVID-19 crisis by the construction of an ethical and social-ecological economy focused of solution for health and climate change issues [64]. The strategy proposed by the European Green Deal to ensure economic growth could be achieved by industry mobilization for a circular and clean economy. This achievement could also solve the medical crisis and provide perspectives for social and economic progress in the next decade as Smol et al. (2020) suggested [65].

Author Contributions: Conceptualization, M.S., T.D. and C.B.P.; methodology, M.S.; formal analysis, M.S. and C.B.P.; resources, M.S., T.D. and C.B.P.; data curation, M.S.; writing-Original draft preparation: M.S.; project administration, M.S., T.D. and C.B.P.; funding acquisition, C.B.P. All authors have read and agreed to the published version of the manuscript.

Funding: This work benefited from the European Union's Horizon 2020 research and innovation programme project BE-Rural funded under agreement No 818478.

Conflicts of Interest: The authors declare no conflict of interest.

\section{References}

1. Haines, A.; Scheelbeek, P. European Green Deal: A major opportunity for health improvement. Lancet 2020, 395, 1327-1329. [CrossRef]

2. Zlaugotne, B.; Ievina, L.; Azis, R.; Baranenko, D.; Blumberga, D. GHG Performance Evaluation in Green Deal Context. Environ. Clim. Technol. 2020, 24, 431-441. [CrossRef]

3. Pfenninger, S.; Keirstead, J. Renewables, nuclear, or fossil fuels? Scenarios for Great Britain's power system considering costs, emissions and energy security. Appl. Energy 2015, 152, 83-93. [CrossRef]

4. Cucchiella, F.; Adamo, I.; Gastaldi, M. Biomethane: A renewable resource as vehicle fuel. Resources 2017, 6, 58. [CrossRef]

5. Blazejczak, J.; Braun, F.G.; Edler, D.; Schill, W.P. Economic effects of renewable energy expansion: A modelbased analysis for germany. Renew. Sustain. Energy Rev. 2014, 40, 1070-1080. [CrossRef]

6. Sinn, H.W. Buffering volatility: A study on the limits of Germany's energy revolution. Eur. Econ. Rev. 2017, 99, 130-150. [CrossRef]

7. Brodny, J.; Tutak, M. Analyzing similarities between the European Union countries in terms of the structure and volume of energy production from renewable energy sources. Energies 2020, 13, 913. [CrossRef]

8. Wu, Q.; Zhou, J.; Liu, S.; Yang, X.; Ren, H. Multi-objective Optimization of Integrated Renewable Energy System Considering Economics and $\mathrm{CO}_{2}$ Emissions. Energy Procedia 2016, 104, 15-20. [CrossRef]

9. Kanagawa, M.; Nakata, T. Assessment of access to electricity and the socio-economic impacts in rural areas of developing countries. Energy Policy 2008, 36, 2016-2029. [CrossRef]

10. Oseni, M. Household's access to electricity and energy consumption pattern in Nigeria. Renew. Sustain. Energy Rev. 2012, 16, 990-995. [CrossRef]

11. COP25 Summary Report. Available online: https://www.ieta.org/resources/Documents/IETA-COP25-Report_ 2019.pdf (accessed on 10 April 2020). 
12. European Commission. Available online: https://ec.europa.eu/info/strategy/priorities-2019-2024/europeangreen-deal_en (accessed on 10 April 2020).

13. Bigerna, S.; D'Errico, M.C.; Polinori, P. Heterogeneous impacts of regulatory policy stringency on the EU electricity Industry: A Bayesian shrinkage dynamic analysis. Energy Policy 2020, 142, 111522. [CrossRef]

14. Kilinc-Ata, N. The evaluation of renewable energy policies across EU countries and US states: An econometric approach. Energy Sustain. Dev. 2016, 31, 83-90. [CrossRef]

15. Haas, R.; Resch, G.; Panzer, C.; Busch, S.; Ragwitz, M.; Held, A. Efficiency and effectiveness of promotion systems for electricity generation from renewable energy sources-Lessons from EU countries. Energy 2011, 36, 2186-2193. [CrossRef]

16. Cucchiella, F.; D'Adamo, I.; Gastaldi, M.; Miliacca, M. Efficiency and allocation of emission allowances and energy consumption over more sustainable European economies. J. Clean. Prod. 2018, 182, 805-817. [CrossRef]

17. European Parliament. Renewable Energy Sources. 2016. Available online: http://www.europarl.europa.eu/ $\mathrm{ftu} / \mathrm{pdf} / \mathrm{lv} /$ FTU_5.7.4.pdf (accessed on 2 June 2020).

18. Ruggiero, S.; Lehkonen, H. Renewable energy growth and the financial performance of electric utilities: A panel data study. J. Clean. Prod. 2017, 142, 3676-3688. [CrossRef]

19. Sari, A.; Akkaya, M. Contribution of renewable energy potential to sustainable employment. Procedia Soc. Behav. Sci. 2016, 229, 316-325. [CrossRef]

20. Li, J.; Zhang, X.; Ali, S.; Khan, Z. Eco-innovation and energy productivity: New determinants of renewable energy consumption. J. Environ. Manag. 2020, 271, 111028. [CrossRef]

21. Šahović, N.; da Silva, P.P. Community Renewable Energy-Research Perspectives. Energy Procedia 2016, 106, 46-58. [CrossRef]

22. IEA. Energy and Climate Change, World Energy Outlook Special Report. Available online: https://www.iea. org/publications/freepublications/publication/WEO2015SpecialReportonEnergyandClimateChange.pdf (accessed on 7 October 2020).

23. Frankfurt School UNEP Centre; Bloomberg New Energy Finance (BNEF). Global Trends in Renewable Energy Investment. Frankfurt School-UNEP Centre. 2016. Available online: http://fs-unep-centre.org/sites/default/ files/attachments/press_release_gtr_2016_in_english.pdf (accessed on 2 October 2020).

24. Thellufsen, J.Z.; Lund, H. Cross-border versus cross-sector interconnectivity in renewable energy systems. Energy 2017, 124, 492-501. [CrossRef]

25. EUR-Lex. Directive 2009/28/EC of the European Parliament and of the Council of 23 April 2009 on the Promotion of the Use of Energy from Renewable Sources and Amending and Subsequently Repealing Directives 2001/77/EC and 2003/30/EC. Available online: http://eur-lex.europa.eu/legal-content/EN/TXT/PDF/ ?uri=CELEX:32009L0028\&from=RO (accessed on 2 October 2020).

26. Eurostat Statistics Explained. Available online: http://ec.europa.eu/eurostat/statistics-explained/index.php/ Glossary:Gross_inland_energy_consumption (accessed on 2 April 2020).

27. Engelken, M.; Römer, B.; Drescher, M.; Welpe, I.M.; Picot, A. Comparing drivers, barriers, and opportunities of business models for renewable energies: A review. Renew. Sustain. Energy Rev. 2016, 60, 795-809. [CrossRef]

28. Soava, G.; Mehedintu, A.; Sterpu, M.; Raduteanu, M. Impact of renewable energy consumption on economic growth: Evidence from European Union countries. Technol. Econ. Dev. Econ. 2018, 24, 1197-1215. [CrossRef]

29. Pappas, S.S.; Ekonomou, L.; Karamousantas, D.C.; Chatzarakis, G.; Katsikas, S.; Liatsis, P. Electricity demand loads modeling using AutoRegressive Moving Average (ARMA) models. Energy 2008, 33, 1353-1360. [CrossRef]

30. Tzeng, G.H.; Shiau, T.A.; Lin, C.Y. Application of multicriteria decision making to the evaluation of new energy system development in Taiwan. Energy 1992, 17, 983-992. [CrossRef]

31. Ozturk, S.; Ozturk, F. Forecasting Energy Consumption of Turkey by Arima Model. J. Asian Sci. Res. 2018, 8, 52-60. [CrossRef]

32. Svenfelt, Å.; Engström, R.; Svane, Ö. Decreasing energy use in buildings by $50 \%$ by 2050 -A backcasting study using stakeholder groups. Technol. Forecast. Soc. Chang. 2011, 78, 785-796. [CrossRef]

33. Aslan, A. The causal relationship between biomass energy use and economic growth in the United States. Renew. Sustain. Energy Rev. 2016, 57, 362-366. [CrossRef]

34. Sasana, H.; Ghozali, I. The impact of fossil and renewable energy consumption on the economic growth in Brazil, Russia, India, China and South Africa. Int. J. Energy Econ. Policy 2017, 7, 194-200. [CrossRef] 
35. Destek, M.A.; Aslan, A. Renewable and non-renewable energy consumption and economic growth in emerging economies: Evidence from bootstrap panel causality. Renew. Energy 2017, 111, 757-763. [CrossRef]

36. Rezitis, A.N.; Ahammad, S.M. The relationship between energy consumption and economic growth in South and Southeast Asian countries: A panel vector autoregression approach and causality analysis. Int. J. Energy Econ. Policy 2015, 5, 704-715. [CrossRef]

37. Resch, G.; Gephart, M.; Steinhilber, S.; Klessmann, C.; del Rio, P.; Ragwitz, M. Coordination or harmonisation? Feasible pathways for a European res strategy beyond 2020. Energy Environ. 2013, 24, 147-170. [CrossRef]

38. Fumon, N.; Biswas, M.A.R. Regression analysis for prediction of residential energy consumption. Renew. Sustain. Energy Rev. 2015, 47, 332-343. [CrossRef]

39. Salim, R.A.; Shafiei, S. Urbanization and renewable and non-renewable energy consumption in OECD countries: An empirical analysis. Econ. Model. 2014, 38, 581-591. [CrossRef]

40. Klessmann, C.; Rathmann, M.; de Jager, D.; Gazzo, A.; Resch, G.; Busch, S.; Ragwitz, M. Policy options for reducing the costs of reaching the European renewables target. Renew. Energy 2013, 57, 390-403. [CrossRef]

41. Collins, S.; Deane, J.P.; Gallachóir, B.Ó. Adding value to EU energy policy analysis using a multi-model approach with an EU-28 electricity dispatch model. Energy 2017, 130, 433-447. [CrossRef]

42. Tsai, S.B.; Xue, Y.; Zang, J.; Chen, Q.; Liu, Y.; Zhou, J.; Dong, W. Models for forecasting growth trends in renewable energy. Renew. Sustain. Energy Rev. 2017, 77, 1169-1178. [CrossRef]

43. Liu, Y. Exploring the relationship between urbanization and energy consumption in China using ARDL (autoregressive distributed lag) and FDM (factor decomposition model). Energy 2009, 34, 1846-1854. [CrossRef]

44. Kao, C. Spurious regression and residual-based tests for cointegration in panel data. J. Econom. 1999, 90, 1-44. [CrossRef]

45. Pedroni, P. Fully modified OLS for heterogeneous cointegrated panels. In Nonstationary Panels, Panel Cointegration, and Dynamic Panels; Emerald Group Publishing Limited: Bentley, UK, 2001.

46. Deryugina, T.; MacKay, A.; Reif, J. The long-run dynamics of electricity demand: Evidence from municipal aggregation. Am. Econ. J. Appl. Econ. 2020, 12, 86-114. [CrossRef]

47. OECD. Real GDP Forecast (Indicator). 2020. Available online: https://data.oecd.org/gdp/real-gdp-forecast. htm (accessed on 23 June 2020).

48. Barak, S.; Sadegh, S. Forecasting energy consumption using ensemble ARIMA-ANFIS hybrid algorithm. Electr. Power Energy Syst. 2016, 82, 92-104. [CrossRef]

49. Borozan, D. Exploring the relationship between energy consumption and GDP: Evidence from Croatia. Energy Policy 2013, 59, 373-381. [CrossRef]

50. Câmpeanu, V.; Pencea, S. Renewable energy sources in Romania: From a "paradise" of investors to a possible abandon or to another boom? The impact of a new paradigm in Romanian renewable sources policy. Procedia Econ. Financ. 2014, 8, 129-137. [CrossRef]

51. Lund, H. Renewable energy strategies for sustainable development. Energy 2007, 32, 912-919. [CrossRef]

52. APREN. Renewable Electricity in Portugal. 2017. Available online: https://apren.pt/.../06-renewableelectricity-in-portugal-2.pdf (accessed on 1 September 2020).

53. Štreimikienè, D.; Balezentis, T. Kaya identity for analysis of the main drivers of ghg emissions and feasibility to implement eu "20-20-20" targets in the Baltic States. Renew. Sustain. Energy Rev. 2016, 58, 1108-1113. [CrossRef]

54. Proença, S.; Aubyn, M.S. Hybrid modeling to support energy-climate policy: Effects of feed-in tariffs to promote renewable energy in Portugal. Energy Econ. 2013, 38, 176-185. [CrossRef]

55. Armeanu, D.Ş.; Gherghina, S..C.; Pasmangiu, G. Exploring the causal nexus between energy consumption, environmental pollution and economic growth: Empirical evidence from central and Eastern Europe. Energies 2019, 12, 3704. [CrossRef]

56. Bhattacharya, M.; Paramati, S.R.; Ozturk, I.; Bhattacharya, S. The effect of renewable energy consumption on economic growth: Evidence from top 38 countries. Appl. Energy 2016, 162, 733-741. [CrossRef]

57. Alola, A.A.; Bekun, F.V.; Sarkodie, S.A. Dynamic impact of trade policy, economic growth, fertility rate, renewable and non-renewable energy consumption on ecological footprint in Europe. Sci. Total Environ. 2019, 685, 702-709. [CrossRef]

58. Oei, P.Y.; Hermann, H.; Herpich, P.; Holtemöller, O.; Lünenbürger, B.; Schult, C. Coal phase-out in Germany-Implications and policies for affected regions. Energy 2020, 196, 117004. [CrossRef] 
59. Armeanu, D.Ş.; Vintilă, G.; Gherghina, Ş.C. Does renewable energy drive sustainable economic growth? multivariate panel data evidence for EU-28 countries. Energies 2017, 10, 381. [CrossRef]

60. Inglesi-Lotz, R. The impact of renewable energy consumption to economic growth: A panel data application. Energy Econ. 2016, 53, 58-63. [CrossRef]

61. Apergis, N.; Payne, J.E.; Menyah, K.; Wolde-Rufael, Y. On the causal dynamics between emissions, nuclear energy, renewable energy, and economic growth. Ecol. Econ. 2010, 69, 2255-2260. [CrossRef]

62. Apergis, N.; Payne, J.E. Renewable energy consumption and economic growth: Evidence from a panel of OECD countries. Energy Policy 2010, 38, 656-660. [CrossRef]

63. Elkerbout, M.; Egenhofer, C.; Núñez Ferrer, J.; Catuti, M.; Kustova, I.; Rizos, V. The European Green Deal after Corona: Implications for EU climate policy. CEPS Policy Insights 2020.

64. Spash, C.L. 'The economy'as if people mattered: Revisiting critiques of economic growth in a time of crisis. Globalizations 2020, 1-18. [CrossRef]

65. Smol, M.; Marcinek, P.; Duda, J.; Szołdrowska, D. Importance of Sustainable Mineral Resource Management in Implementing the Circular Economy (CE) Model and the European Green Deal Strategy. Resources 2020, 9, 55. [CrossRef]

Publisher's Note: MDPI stays neutral with regard to jurisdictional claims in published maps and institutional affiliations.

(C) 2020 by the authors. Licensee MDPI, Basel, Switzerland. This article is an open access article distributed under the terms and conditions of the Creative Commons Attribution (CC BY) license (http://creativecommons.org/licenses/by/4.0/). 